PROBLEMS

OF EDUCATION IN THE $21^{\text {st }}$ CENTURY Vol. 79 , No. 1, 2021

\section{ADOLESCENTS' PREFERENCES FOR MEDIA CONTENT AND THEIR PERCEPTIONS OF DOMINANT VALUE ORIENTATIONS IN THE MEDIA}

\author{
Bisera Jevtić, Danijela Milošević \\ University of Niš, Republic of Serbia \\ E-mail: bisera.jevtic@filfak.ni.ac.rs, danijelamilosevic1993@gmail.com
}

\begin{abstract}
Today, the media represent one of the main factors in the upbringing and education of adolescents due to the growing representation, availability of diverse content and more frequent use. In adolescence, the media have a special significance, because they greatly influence the preferences, attitudes, emotions, behavior, value orientations and the formation of adolescents' identities. Starting from such an attitude, the preferences of upper-secondary school students for monitoring media content and their perceptions of value orientations that are promoted through the media were examined through the aim of the research. The media habits of adolescents and their perceptions of the value system in the media were determined through the survey technique. The study included 433 students from the Republic of Serbia. The results showed that there are significant differences in the preferences of adolescents in the choice of media content in relation to gender and type of school. A positive correlation was found in the monitoring of certain television content and values in the media, as well as in relation to musical affinities and values that are promoted through music videos. The results of research point out potential proposals for improving the media culture of adolescents and reducing the negative effects of the media. It is recognized as a potential solution in the development of media literacy of adolescents, i.e., the affirmation of their critical opinion about the messages and values that are promoted through the media.
\end{abstract}

Keywords: media literacy, media values, students' media preferences, students' perception, value orientations

\title{
Introduction
}

Research into media culture and the impact it has on the formation of the youth value system is increasingly becoming a subject of interest for researchers. Due to the increasing representation and frequent use, mass media (TV programs, virtual media, press, radio) are a powerful factor in upbringing and education.

Since they are an integral part of the everyday social environment of children and youth, the media with their content influence the development and shaping of attitudes, beliefs and opinions of individuals (Eisen \& Lillard, 2017; Kearney \& Levine, 2020), as well as social norms, values, personal principles and worldviews (Gajić \& Lungulov, 2012). By providing information, entertainment and opportunities for learning, sensations, cultural identification and identity formation, the media stimulate cognitive and emotional processes and participate in the socialization of children and youth. On the other hand, faced with poor content, children and young people accept it in unlimited quantities, as an escape from problems, seeking entertainment, compensation and replacement. The amount of such content affects the acceptance of the imposed values that lead to meaninglessness, dehumanization and the denial of the highest values (Jevtić, 2012). Consequently, the media can be dangerous and have a 
Bisera JEVTIĆ, Danijela MILOŠEVIĆ. Adolescents' preferences for media content and their perceptions of dominant value orientations in the media

PROBLEMS

OF EDUCATION

IN THE $21^{\text {st }}$ CENTURY

Vol. 79, No. 1, 2021

significant impact on children and young people, as they offer patterns of behavior that affirm some and disavow others (Tompson, 2003). Too much fun leads to moral ruin (Oliver \& Raney, 2014), and the high level of constant exposure of children and young people to different media creates the possibility of negative influence (Kartal, 2018).

Media content leaves the biggest mark in adolescence, which is the most sensitive period of personality development of each individual (Plaisier \& Konijn, 2013). The results of research in the Republic of Serbia, but also in other countries showed a constant increase in the use of media, whose content negatively affects the behavior of adolescents (Bulu et al., 2016; Kuzmanović et al., 2019; Labaš, 2018; Popadić \& Kuzmanović, 2016). Inadequate media content promotes negative behaviors of adolescents, and the consumption of violent content leads to the adoption of such a model of behavior (Coyne, 2016; Siddiqui \& Singh, 2016). The danger of negative influences is greater because the current digital generation is subjected to the acceptance of values imposed by the media (Vuksanović, 2018).

Many studies have shown the negative impact of media content on the behavior and value formation of adolescents. Earlier results have shown that the long-term consequences of consuming inadequate media content leave a greater mark on adolescents who show increased tendencies towards antisocial behavior (Slater et al., 2003). Due to increased aggression and frequent viewing of violent content, desensitization and acceptance of violent behavior occur as an acceptable way of resolving conflict (Krahé et al., 2011). Other findings have shown that adolescents who constantly monitor inadequate content, while belonging to a riskier group, are more likely to identify with negative characters (Zilka \& Romi, 2018). Adolescent exposure to inadequate content results in both risky sexual behavior and low school achievement (Dhawale, 2017). This is supported by research that has shown that media coverage of tobacco, drugs, violence and beauty can cause short-term or long-term changes in adolescents' behavior and values (Hughes et al., 2010). The same results were obtained when it comes to new social media, which showed that greater exposure to antisocial media content on the Internet (videos, music videos, photos, texts) causes negative behavior among adolescents (Hamer \& Konijn, 2015).

Due to the frequent use of the media, the growing presence of inadequate media content and their negative impact on the attitudes, values and behavior of adolescents, it was concluded that this area should be given more attention in the scientific community. Considering that there is no similar research in the Republic of Serbia, it is not possible to get a realistic picture of the current situation and find adequate potential solutions, which was another motive for starting this research. Accordingly, the aim of the research was to examine adolescents' preferences for media content and the connection with their perceptions of value orientations in the media.

\section{Research Questions}

Research questions were:

1) What media content is preferable to the students?

2) What is the correlation between the value orientation which students recognize in the media with the content they follow?

\section{Research Methodology}

\section{General Background}

Given that the media in the 21 st century are significant agents of educating children and young people, their dominance is manifested in the creation of their values and behavior in everyday life. Therefore, it can be said that adolescents' exposure to different media contents 
Bisera JEVTIĆ, Danijela MILOŠEVIĆ. Adolescents' preferences for media content and their perceptions of dominant value orientations in the media

PROBLEMS

OF EDUCATION

IN THE $21^{\text {st }}$ CENTURY Vol. 79 , No. 1,202

leaves a mark on their personality and value orientations. Although many studies have aimed to examine adolescents' preferences for the use of media content (Anderson \& Bushman, 2001; Gentile et al., 2007), as far as we are aware there is no research that has addressed the association with their perception of value systems in the media. Accordingly, the following research tasks were set:

1) Identify the dominant thematic content that adolescents read through the media;

2) Identify adolescents' favorite television content and their connection with value orientations in the media;

3) Determine the musical affinities of adolescents and the connection with the values they recognize in music videos;

4) Determine which values adolescents recognize as the most represented in the media.

Sample

Upper-secondary education in the Republic of Serbia implies only one level lasting for four years. In Serbia in 2019, there were 249455 students registered in the upper-secondary schools (https://www.stat.gov.rs/en-us/oblasti/obrazovanje/srednje-obrazovanje/). For the purpose of this research, a total of 433 upper-secondary school students, aged 15 to 18 , were surveyed. According to the total population, the sample of 433 respondents meets the $95 \%$ reliability criterion. Random sampling was used in the selection of students, which is the basis of other sampling techniques (Richardsonet et al., 1995). In relation to gender, 58 (36.5\%) male and $275(63.5 \%)$ female students took part. Regarding the type of school, $176(40.6 \%)$ general and $257(59.4 \%)$ vocational students participated. The students live in small and large areas, and $217(50.1 \%)$ students from Kuršumlija, 136 (31.4\%) from Niš and 80 (18.5\%) students from Bor were surveyed. The students voluntarily signed the consent for participation. When giving the consent to students, the anonymity and confidentiality of their personal data was guaranteed.

\section{Instrument and Procedure}

The survey used a questionnaire with close-ended questions. The questionnaire contains questions of a polytomy format (multiple choice questions). The questionnaire examines different segments related to students' reading habits, choices and reasons for opting for music styles, following television content and moral values promoted through music videos and media. The questionnaire consists of 47 questions that students answered with 'yes' or 'no'. The questionnaire was designed for the purpose of this research and it's reliability and validity was tested. Cronbach's alpha coefficient was used for measuring the reliability of the instruments, and scores on the questionnaire were found to be .73 , which indicated that the questionnaire is reliable to be used in this research. The normality of distribution has been tested by KolmogorovSmirnov and Shapiro-Wilk tests, and the results have the level of significance of .001.

\section{Data Analysis}

Corresponding statistical procedures were used in line with the examined problem which would enable the presentation of the obtained data and their analysis. The following processing methods and data analysis were used: percentage and frequency, chi-squared test to determine statistically significant differences between variables and Pearson's correlation analysis to determine the degree of correlation of the variables. The reliability of internal consistency between questions was determined by Cronbach's alpha coefficient. The normality 
Bisera JEVTIĆ, Danijela MILOŠEVIĆ. Adolescents' preferences for media content and their perceptions of dominant value orientations in the media

of distribution was verified by Kolmogorov-Smirnov and Shapiro-Wilk tests. Statistical Vol. 79, No. 1, 2021

analyses were performed in SPSS.25. software package.

\section{Research Results}

The first research task examined upper-secondary school students' preferences for the media content they read the most. The students were offered various thematic content (ecology, politics, sports, family, love, etc.) to which they responded by choosing one of the two options ('Yes' or 'no'). Table 1 shows the obtained in relation to male and female students.

\section{Table 1}

Differences in Preferences of Adolescents about the Thematic Content Based on Gender

\begin{tabular}{|c|c|c|c|c|c|}
\hline \multirow{2}{*}{ Topics } & \multirow{2}{*}{ Gender } & \multicolumn{2}{|c|}{ Yes } & \multicolumn{2}{|c|}{ No } \\
\hline & & $N$ & $\%$ & $N$ & $\%$ \\
\hline \multirow{2}{*}{ Ecology } & Male & 6 & 3.8 & 152 & 96.2 \\
\hline & Female & 15 & 5.5 & 260 & 94.5 \\
\hline \multirow{2}{*}{ Politics } & Male & 33 & 20.9 & 125 & 79.1 \\
\hline & Female & 22 & 8.9 & 253 & 92.0 \\
\hline \multirow{2}{*}{ Sport } & Male & 101 & 63.9 & 57 & 36.1 \\
\hline & Female & 59 & 21.5 & 216 & 78.5 \\
\hline \multirow{2}{*}{ Family } & Male & 4 & 2.5 & 154 & 97.5 \\
\hline & Female & 16 & 5.8 & 259 & 94.2 \\
\hline \multirow{2}{*}{ Sex } & Male & 61 & 38.6 & 97 & 61.4 \\
\hline & Female & 30 & 10.9 & 245 & 89.1 \\
\hline \multirow{2}{*}{ Appearance } & Male & 17 & 10.8 & 141 & 89.2 \\
\hline & Female & 138 & 50.2 & 137 & 49.8 \\
\hline \multirow{2}{*}{ School } & Male & 14 & 8.9 & 144 & 91.1 \\
\hline & Female & 25 & 9.1 & 250 & 90.9 \\
\hline \multirow{2}{*}{ Fashion } & Male & 26 & 16.5 & 132 & 83.5 \\
\hline & Female & 147 & 53.5 & 128 & 46.5 \\
\hline \multirow{2}{*}{ Love } & Male & 6 & 3.8 & 152 & 96.2 \\
\hline & Female & 132 & 48.0 & 143 & 52.0 \\
\hline \multirow{2}{*}{ Behavior } & Male & 22 & 13.9 & 136 & 86.1 \\
\hline & Female & 61 & 22.2 & 214 & 77.8 \\
\hline \multirow{2}{*}{ Friendship } & Male & 22 & 13.9 & 136 & 86.1 \\
\hline & Female & 74 & 26.9 & 201 & 73.1 \\
\hline \multirow{2}{*}{ Celebrities } & Male & 44 & 27.8 & 114 & 72.2 \\
\hline & Female & 150 & 54.5 & 125 & 45.5 \\
\hline
\end{tabular}

Table 1 presents the frequencies and percentages of male and female student preferences in relation to the thematic content. It was found that male students have different preferences in reading thematic content compared to female students. Political (20.9\%), sports $(63.9 \%)$ and sexual content (38.6\%) are preferred by male members. On the other hand, the results showed that female students prefer to read topics about physical appearance $(50.2 \%)$, fashion (53.5\%), love (48.0\%), youth behavior (22.2\%), friendship (26.9\%) and celebrities (54.5\%). 
Bisera JEVTIĆ, Danijela MILOŠEVIĆ. Adolescents' preferences for media content and their perceptions of dominant value orientations in the media

OF EDUCATION

IN THE $21^{\text {st }}$ CENTURY

Vol. 79, No. 1, 2021

No differences in gender preferences were found when it comes to reading environmental, family and school topics. More specifically, over $90 \%$ of students showed no interest in reading environmental, family and school topics.

The focus of the second research task was to identify the television programs that students most often watched. For this purpose, percentages were calculated, and a null hypothesis was tested using the chi-square assuming that there were no differences in students' preferences towards television coverage based on the place of residence. The results are shown in Table 2.

Table 2

Students' Preferences for Television Programs Based on Gender

\begin{tabular}{|c|c|c|c|c|c|c|c|c|}
\hline \multirow{2}{*}{ Television program } & \multirow{2}{*}{ Gender } & \multicolumn{2}{|c|}{ Yes } & \multicolumn{2}{|c|}{ No } & \multirow[b]{2}{*}{$\chi^{2}$} & \multirow{2}{*}{$d f$} & \multirow[b]{2}{*}{$p$} \\
\hline & & $N$ & $\%$ & $N$ & $\%$ & & & \\
\hline \multirow{2}{*}{ Political shows } & Male & 24 & 15.2 & 134 & 84.8 & \multirow{2}{*}{12.784} & \multirow{2}{*}{1} & \multirow{2}{*}{.001} \\
\hline & Female & 14 & 5.1 & 264 & 94.9 & & & \\
\hline \multirow{2}{*}{$\begin{array}{l}\text { Cultural and artistic } \\
\text { shows }\end{array}$} & Male & 19 & 12.0 & 139 & 88.0 & \multirow{2}{*}{.155} & \multirow{2}{*}{1} & \multirow{2}{*}{.473} \\
\hline & Female & 27 & 9.8 & 248 & 90.2 & & & \\
\hline \multirow{2}{*}{ Educational program } & Male & 11 & 7.0 & 147 & 93.0 & \multirow{2}{*}{0.000} & \multirow{2}{*}{1} & \multirow{2}{*}{.983} \\
\hline & Female & 19 & 6.9 & 256 & 93.1 & & & \\
\hline \multirow{2}{*}{ Documentary program } & Male & 62 & 39.2 & 96 & 60.8 & \multirow{2}{*}{31.587} & \multirow{2}{*}{1} & \multirow{2}{*}{.001} \\
\hline & Female & 42 & 15.3 & 233 & 64.7 & & & \\
\hline \multirow{2}{*}{$\begin{array}{l}\text { Programs for children } \\
\text { and youth }\end{array}$} & Male & 5 & 3.2 & 153 & 96.8 & \multirow{2}{*}{4.485} & \multirow{2}{*}{1} & \multirow{2}{*}{.034} \\
\hline & Female & 23 & 8.4 & 252 & 91.6 & & & \\
\hline \multirow{2}{*}{ Cartoons } & Male & 35 & 22.2 & 123 & 77.8 & \multirow{2}{*}{12.281} & \multirow{2}{*}{1} & \multirow{2}{*}{.001} \\
\hline & Female & 106 & 38.5 & 169 & 61.5 & & & \\
\hline \multirow{2}{*}{ Sports programs } & Male & 92 & 58.2 & 66 & 41.8 & \multirow{2}{*}{53.198} & \multirow{2}{*}{1} & 001 \\
\hline & Female & 64 & 23.3 & 211 & 76.7 & & & .001 \\
\hline Fun and artistic & Male & 49 & 31.0 & 109 & 69.0 & & & \\
\hline programs & Female & 113 & 41.1 & 162 & 58.9 & 4.353 & 1 & .037 \\
\hline Quizzes and & Male & 70 & 44.3 & 88 & 55.7 & $655 \mathrm{t}$ & 1 & 010 \\
\hline competitions & Female & 88 & 32.0 & 187 & 68.0 & 0.535 & 1 & .010 \\
\hline & Male & 118 & 74.7 & 40 & 25.3 & 601 & 1 & 106 \\
\hline Miovies and sentes & Female & 215 & 78.2 & 60 & 21.8 & .091 & 1 & .400 \\
\hline
\end{tabular}

The results presented in Table 2 show that a significant statistical difference was found at the level of $p<.05$ in relation to the students' gender. Therefore, the difference was measured between watching certain television content and the students' gender. Accordingly, it has been found that political shows, documentaries and sports programs are more covered by male than the female students. Significant differences in relation to gender were also found in the programs for children and youth, cartoons, quizzes and competitions and entertainment programs, where this content is more represented among the female students. In general, students are least likely to follow educational programs, programs for children and youth, cultural, artistic and political 
Bisera JEVTIĆ, Danijela MILOŠEVIĆ. Adolescents' preferences for media content and their perceptions of dominant value orientations in the media

shows. Resultantly, it turned out that of all the above content, students watch movies and series the most.

In order to determine whether there is a positive or negative correlation, a correlation was measured between the monitoring of certain television content and the value orientations represented in the media. Table 3 presents the results of the calculated correlation.

Table 3

Correlation between TV Content and Media Values

\begin{tabular}{|c|c|c|c|c|c|c|}
\hline $\begin{array}{l}\text { Television } \\
\text { Programs }\end{array}$ & & $\begin{array}{l}\text { Physical } \\
\text { appearance }\end{array}$ & Wealth & Respect & Popularity & Traditionalism \\
\hline \multirow{2}{*}{ Political shows } & $r$ & -.019 & .031 & $.170^{* *}$ & .050 & .017 \\
\hline & $p$ & .698 & .525 & .000 & .299 & .725 \\
\hline \multirow{2}{*}{$\begin{array}{l}\text { Cultural and } \\
\text { artistic shows }\end{array}$} & $r$ & .088 & .033 & .017 & .076 & $.142^{* *}$ \\
\hline & $p$ & .067 & .490 & .729 & .114 & .003 \\
\hline \multirow{2}{*}{$\begin{array}{l}\text { Educational } \\
\text { programs }\end{array}$} & $r$ & -.051 & .046 & -.004 & $.132^{* *}$ & -.047 \\
\hline & $p$ & .294 & .340 & .928 & .006 & .328 \\
\hline \multirow{2}{*}{$\begin{array}{l}\text { Programs for } \\
\text { children and } \\
\text { youth }\end{array}$} & $r$ & -.004 & .051 & $.116^{*}$ & $.122^{*}$ & .005 \\
\hline & $p$ & .931 & .294 & .016 & .011 & .911 \\
\hline \multirow{2}{*}{ Sports programs } & $r$ & -.093 & $.098^{*}$ & .029 & .023 & -.021 \\
\hline & $p$ & .052 & .042 & .554 & .636 & .660 \\
\hline \multirow{2}{*}{$\begin{array}{l}\text { Fun and artistic } \\
\text { programs }\end{array}$} & $r$ & .050 & .007 & .001 & .084 & $.105^{*}$ \\
\hline & $p$ & .297 & .887 & .983 & .081 & .028 \\
\hline \multirow{2}{*}{$\begin{array}{l}\text { Quizzes and } \\
\text { competitions }\end{array}$} & $r$ & .017 & $.115^{*}$ & .012 & .080 & -.013 \\
\hline & $p$ & .727 & .017 & .807 & .097 & .791 \\
\hline \multirow{2}{*}{$\begin{array}{l}\text { Movies and } \\
\text { series }\end{array}$} & $r$ & .078 & $.144^{* *}$ & .026 & $.151^{* *}$ & .045 \\
\hline & $p$ & .106 & .003 & .591 & .002 & .350 \\
\hline
\end{tabular}

Note: *Correlation at the level of $.05 .{ }^{* *}$ Correlation is at the level of .01 .

A positive and negative correlation was obtained between the monitoring of certain media content and the values that are promoted through them. The measured correlation was expressed by Pearson's correlation coefficient (Table 3). The results showed that a high level of monitoring of political content and programs for children and youth is positively correlated with the value of respect. Intensive monitoring of the cultural and entertainment program is accompanied by a high appreciation of traditionalism while watching sports programs, quizzes and prize games, movies and series positively correlates with the value orientation of wealth. The greater the scope of monitoring media content in the field of education, programs for children and youth and films and series, the more it contributes to the recognition of the value orientation of popularity. A weak negative correlation was found between sports program and physical appearance, with a high level of viewing sports programs followed by a low level of recognition of physical appearance.

The third research task examined adolescents' preferences for music genres. The percentages are shown in Table 4. 
Bisera JEVTIĆ, Danijela MILOŠEVIĆ. Adolescents' preferences for media content and their perceptions of dominant value orientations in the media

OF EDUCATIC IN THE $21^{\text {st }}$ CENTURY Vol. 79 , No. 1,2021

Table4

Adolescent Music Preferences according to the Type of School

\begin{tabular}{|c|c|c|c|c|c|}
\hline \multirow{2}{*}{ Genre } & \multirow{2}{*}{ Type of school } & \multicolumn{2}{|c|}{ Yes } & \multicolumn{2}{|c|}{ No } \\
\hline & & $N$ & $\%$ & $N$ & $\%$ \\
\hline \multirow{2}{*}{ Folk } & General & 28 & 15.9 & 148 & 84.1 \\
\hline & Vocational & 67 & 26.1 & 190 & 73.9 \\
\hline \multirow{2}{*}{ Pop } & General & 63 & 35.8 & 113 & 64.2 \\
\hline & Vocational & 66 & 25.7 & 191 & 74.3 \\
\hline \multirow{2}{*}{ Rock } & General & 34 & 19.3 & 142 & 80.7 \\
\hline & Vocational & 15 & 5.8 & 242 & 94.2 \\
\hline \multirow{2}{*}{ Rap/Hip-hop } & General & 35 & 19.9 & 141 & 80.1 \\
\hline & Vocational & 52 & 20.2 & 205 & 79.8 \\
\hline \multirow{2}{*}{ Techno } & General & 20 & 11.4 & 156 & 88.6 \\
\hline & Vocational & 44 & 17.1 & 213 & 82.9 \\
\hline \multirow{2}{*}{ All styles } & General & 84 & 47.7 & 92 & 52.3 \\
\hline & Vocational & 113 & 44.0 & 144 & 56.0 \\
\hline
\end{tabular}

The results presented in Table 3 indicate that there are differences in listening to a particular genre of music in relation to the type of school that students attend. While general school students most often prefer pop (35.8\%), vocational students highlight folk (26.1\%). On the other hand, the genre that general school students opt for the least is techno $(88.6 \%)$ and vocational school students rock $(94.2 \%)$. There were no differences in response to the type of school in terms of listening to all genres and rap/hip-hop.

The correlation between the inclination towards a certain musical style and value orientations in music videos is expressed through Pearson's correlation coefficient. The results are presented in Table 5.

\section{Table 5}

Correlation between Type of Music and Value Orientations in Music Videos

\begin{tabular}{|c|c|c|c|c|c|c|}
\hline Values & & Folk & Pop & Rock & Rap & Techno \\
\hline \multirow{2}{*}{$\begin{array}{l}\text { Expensive cars and } \\
\text { branded wardrobe }\end{array}$} & $r$ & .071 & $.100^{*}$ & .052 & .064 & $.095^{\star}$ \\
\hline & $p$ & .141 & .038 & .282 & .181 & .048 \\
\hline \multirow{2}{*}{ Criminal behavior } & $r$ & .028 & $.176^{*}$ & .027 & $.174^{\star *}$ & .043 \\
\hline & $p$ & .556 & .000 & .578 & .000 & .368 \\
\hline \multirow{2}{*}{ Sexual intercourse } & $r$ & -.035 & $.100^{*}$ & .083 & .055 & .042 \\
\hline & $p$ & .463 & .037 & .086 & .250 & .384 \\
\hline \multirow{2}{*}{ Love stories } & $r$ & $.124^{* *}$ & .068 & -.038 & $.107^{*}$ & .060 \\
\hline & $p$ & .010 & .156 & .431 & .025 & .209 \\
\hline \multirow{2}{*}{ Friendship } & $r$ & .016 & -.092 & -.075 & .030 & .077 \\
\hline & $p$ & .740 & .056 & .119 & .537 & .112 \\
\hline \multirow{2}{*}{ Violence } & $r$ & $-.104^{*}$ & .031 & .053 & $.130^{* *}$ & $.142^{* *}$ \\
\hline & $p$ & .031 & .519 & .273 & .007 & .003 \\
\hline \multirow{2}{*}{ Free life } & $r$ & .002 & -.016 & -.066 & .013 & $.188^{* *}$ \\
\hline & $p$ & .965 & .742 & .170 & .792 & .001 \\
\hline
\end{tabular}

Note: *Correlation at the level of .05. ${ }^{* *}$ Correlation is at the level of .01. 
Bisera JEVTIĆ, Danijela MILOŠEVIĆ. Adolescents' preferences for media content and their perceptions of dominant value orientations in the media

PROBLEMS

OF EDUCATION

IN THE $21^{\text {st }}$ CENTURY

Vol. 79, No. 1, 2021

Table 5 shows that a positive and negative correlation was found between the musical style of upper-secondary school students and value orientations in music videos. Listening to folk music positively correlates $(r=.124, p<.05)$ with recognizing love moments in music videos. On the other hand, the preference for folk music was negatively correlated $(r=-.104$, $p<.05$ ) with the recognition of violence. A high level of listening to pop music is accompanied by a high level of recognizing and promoting material values and risky behaviors (criminal behavior and sexual intercourse). A positive correlation also occurs with rap music, with uppersecondary school students who listen to this type of music more often noticing that criminal behavior $(r=.174, p<.05)$ and violence are promoted in music videos $(r=.130, p<.05)$. The inclination towards techno music contributes to the recognition of the propagation of material values and violence, but also of the free way of life. No connection was found when it comes to rock music and the offered value orientations.

Table 6

Adolescents' perceptions about the Value System in the Media based on Place of Residence

\begin{tabular}{|c|c|c|c|c|c|c|c|c|c|c|}
\hline \multirow{3}{*}{ Values } & & \multicolumn{6}{|c|}{ Place of residence } & \multirow{3}{*}{$\chi^{2}$} & \multirow{3}{*}{$d f$} & \multirow{3}{*}{$p$} \\
\hline & & \multicolumn{2}{|c|}{ Kuršumlija } & \multicolumn{2}{|c|}{ Niš } & \multicolumn{2}{|c|}{ Bor } & & & \\
\hline & & $N$ & $\%$ & N & $\%$ & $N$ & $\%$ & & & \\
\hline \multirow{2}{*}{ Physical appearance } & Yes & 154 & 71.0 & 76 & 55.9 & 67 & 83.8 & \multirow{2}{*}{199.298} & \multirow{2}{*}{2} & \multirow{2}{*}{.001} \\
\hline & No & 63 & 29.0 & 60 & 44.1 & 13 & 16.2 & & & \\
\hline \multirow{2}{*}{$\begin{array}{l}\text { Expensive things } \\
\text { and wealth }\end{array}$} & Yes & 145 & 66.8 & 49 & 36.0 & 56 & 70.0 & \multirow{2}{*}{40.034} & \multirow{2}{*}{2} & \multirow{2}{*}{.001} \\
\hline & No & 72 & 33.2 & 87 & 64.0 & 24 & 30.0 & & & \\
\hline \multirow{2}{*}{$\begin{array}{l}\text { Respect among } \\
\text { peers }\end{array}$} & Yes & 50 & 23.0 & 40 & 29.4 & 14 & 17.5 & \multirow{2}{*}{4.144} & \multirow{2}{*}{2} & \multirow{2}{*}{.126} \\
\hline & No & 167 & 77.0 & 96 & 70.6 & 66 & 82.5 & & & \\
\hline \multirow{2}{*}{$\begin{array}{l}\text { Being famous and } \\
\text { popular }\end{array}$} & Yes & 147 & 67.7 & 72 & 52.9 & 55 & 68.8 & \multirow{2}{*}{9.146} & \multirow{2}{*}{2} & \multirow{2}{*}{.010} \\
\hline & No & 70 & 32.3 & 64 & 47.1 & 25 & 31.2 & & & \\
\hline \multirow{2}{*}{ Humanitarian work } & Yes & 31 & 14.3 & 30 & 22.1 & 10 & 12.5 & \multirow{2}{*}{4.772} & \multirow{2}{*}{2} & \multirow{2}{*}{.092} \\
\hline & No & 186 & 85.7 & 106 & 77.9 & 70 & 87.5 & & & \\
\hline \multirow{2}{*}{ Traditionalism } & Yes & 32 & 14.7 & 29 & 21.3 & 13 & 16.2 & \multirow{2}{*}{2.601} & \multirow{2}{*}{2} & \multirow{2}{*}{.272} \\
\hline & No & 185 & $85.3 \%$ & 107 & 78.7 & 67 & 83.8 & & & \\
\hline
\end{tabular}

Table 6 shows the obtained chi-squared test value for all claims, and the three shows a significance level of $p<.01$. Significant differences in students' responses were found in relation to their place of residence. Students from the smallest area (Kuršumlija) estimated more than those from the larger city (Bor) to promote physical appearance through media content. Differences also occur in relation to expensive things and wealth, where students from the smallest city (Kuršumlija) also showed a critical attitude and recognized the presence of this value more than students from the largest city (Niš). Wealth and popularity are highly valued, where it is recognized more by students from Kuršumlija than from Bor and Niš. No differences compared to other values were found. However, it is noticed that the students recognized as the least represented values in the media: respect among peers, humanitarian work and traditionalism, with the fact that students from the largest environment (Niš) slightly more positively assessed their representation in the media. Thus, it is evident that students from smaller places are more likely than those from larger areas to recognize more negative values that are promoted in media content than positive ones. 
Bisera JEVTIĆ, Danijela MILOŠEVIĆ. Adolescents' preferences for media content and their perceptions of dominant value orientations in the media

PROBLEMS

OF EDUCATION

IN THE $21^{\text {st }}$ CENTURY Vol. 79 , No. 1,2021

42

\section{Discussion}

By determining students' preferences for the use of media content the significant results were obtained. It is found that students differ in their propensity to read certain media content in relation to gender. While males are oriented towards reading political, sports and sex content, females mostly read topics about looks, fashion, love and celebrities. The results are in line with a survey conducted in Croatia, which showed that females are preoccupied with everyday topics and content related to appearance, and males read more about sex than them (Ilišin et al., 2001; Ilišin, 2006). The difference that was determined in the preferences indicates the existence of different patterns of behavior and socialization of boys and girls. Apparently, that relationship has not changed for decades, and in adolescents, such content leaves negative effects, which is confirmed by other research. One of them showed that reading content about appearance influenced the formation of a negative image of oneself and the internalization of the value of beauty that is propagated through the media (Rousseau et al., 2018). Another study found that media content has a greater impact on girls when it comes to their appearance, and on boys when it comes to comparisons in sports. For boys, watching content about sports had positive effects, in terms of inspiration to achieve sports effects, and for girls it caused negative emotions (Tatangelo \& Ricciardelli, 2017). The popular media press is dominated by the sexualization of girls, so some research has confirmed that under the influence of reading and following celebrities, girls begin to express their sexuality earlier and to internalize such values (Jackson \& Vares, 2015; McKenney \& Bigler, 2016). Adolescents are particularly sensitive to their physical appearance and therefore tend to look as beautiful as possible in order to be accepted by others (Bowker et al., 2013). This can also be one of the reasons why girls prefer this type of content. When it comes to other contents, the weak interest in reading environmental, school and other topics can be seen through the weak offer of the media. Such topics, in addition to being less represented, are also less attractive for students to read. In a recent study of adolescents, their low propensity to read such topics has been confirmed (Zilka, 2018).

When it comes to television content, the results indicate a low level of students' interest in educational, cultural and political content and orientation towards those who offer entertainment, as shown by previous research (Ilišin et al., 2001; Medrano et al., 2007; Tayo et al., 2019). It was also determined that political shows, documentaries and sports programs are more watched by members of the male sex, and that programs for young people, cartoons, quizzes and prize games and entertainment programs are watched more by females. However, of all the content, adolescents mostly watch movies and series. The results are consistent with other research, which showed that boys are more inclined to follow sports content, and girls to entertaining, as well as that adolescents watch movies and series the most, and the least media content in the field of art and documentary program (Zilka, 2018). These results meet the predicted expectations that adolescents watch television passively and that their entertainment content is more attractive than others. The most youth-oriented film industry offers content that is often inadequate and that can lead to moral degradation. The content that is broadcast in movies and series does not show a realistic picture of life. Such content sends a message of a glamorous and ideal life that is almost impossible to achieve.

The results also indicate that a high level of monitoring of entertainment programs contributes to the recognition of wealth and popularity as value orientations present in the media. On the other hand, adolescents who follow educational and cultural shows are more likely to notice values (respect and traditionalism) in the media. The results suggest that viewing certain content may affect the perception of different value orientations. Given that inadequate and programs of less quality are more prevalent, there is also a greater danger and risk for the adoption of such values in adolescents. 
The emergence of musical eclecticism is the expected result obtained by examining the music styles of youth. The genres of pop (general school) and folk (vocational school) are popular with young people, but no less are other genres (rock, hip-hop and techno) represented. That pop is the most listened type of music has been proven in other research, with different results being obtained that rap music is the least listened to among young people (Altun et al., 2018; Bulut et al., 2012; Sağır \& Öztürk, 2015). This research has shown that most students prefer all musical styles (traditional and modern), which is the expected answer, because adolescents are still in the process of building their musical identity. The obtained results can be justified by the fact that today's commercialized music has led to the mixing of different styles, and thus gained more attention of adolescents. However, when it comes to recognizing negative values in music videos, the obtained results indicate that adolescents who listen to folk music recognized them the least, which is not the case for other music genres (pop, techno and rap). Shah (2017) pointed out that today's music videos are the embodiment of the promotion of free life, violence and fornication. In promoting such values, the music videos of rap music, which is increasingly present among adolescents, are at the forefront. The current musical culture being considered, it can be noticed that the western contexts brought a variety of musical genres that became part of the life of youth in the territory of the Republic of Serbia and that they had accepted them. Although music videos can be a common inspiration in presenting lyrics, their content reflects the value system of society and offers a model of behavior to young generations. Based on the current offer, it can be said that music production has become a means of promoting low cultural habits and values that offers inadequate models of behavior to young generations.

The assumption that there are statistically significant differences in young people's perception about the value system in the media in relation to the place of residence is confirmed. Most young people believe that negative values are most present in the media, and this may be due to giving more media space to such content. Young people from larger cities believe that positive values are more represented in the media than young people from smaller cities. These results indicate that young people from smaller communities took a more critical stance on perceiving values in the media. On the other hand, the results also indicate the consideration of the family context, that is, possible differences in education and socialization between young people from smaller and larger areas. The findings of research conducted in Pakistan confirmed that media content mostly promotes materialistic values and greed for money and popularity (Shah, 2017). Given that the same values were stated by adolescents as the most common, it can be concluded that there is awareness of the negative value system in the media, but it cannot be claimed that such content will not leave a negative impact on the development of identity and value orientations of children and youth.

\section{Conclusions and Implications}

This research sought to examine students' preferences for the use of media content and the relationship with their perception of values in the media. Based on the obtained research results, significant findings pointed out in terms of adolescents' preferences for the use of media content. First, different preferences of adolescents regarding reading content and watching television programs in relation to gender were identified. Second, significant differences in the musical affinities of adolescents in relation to the type of school were found. When it comes to adolescents' perceptions of value orientations, important findings have also been obtained. First, significant differences were found in the perception of positive and negative value orientations of adolescents from smaller and larger communities. Second, adolescents recognized the high level of representation of negative value orientations and showed that they have a developed awareness of neglection of positive value orientations of the media. 
Bisera JEVTIĆ, Danijela MILOŠEVIĆ. Adolescents' preferences for media content and their perceptions of dominant value orientations in the media

PROBLEMS

OF EDUCATION IN THE $21^{\text {st }}$ CENTURY Vol. 79 , No. 1,2021

44

Regarding the connection between adolescents' preferences for monitoring media content and their perceptions of value orientations, it can be concluded that the media content that adolescents in the Republic of Serbia prefer differentiates the way they perceive values in the media. More precisely, the preferences for monitoring media content contribute to the perception of positive or negative value orientations in the media.

The fact that adolescents recognize negative value orientations in the media shouldn't be ignored, but also prefer media content that has a negative connotation. In this regard, there is a need to develop strategies to reduce the possibility of negative action and increase the level of conscious and critical thinking of upper secondary school students. Accordingly, the joint action of the family, school and other institutions in the development of media literacy of adolescents is recommended. In the family environment, parents can nurture media culture from an early age, talk to their children about the content that is broadcast through the media and direct them to adequate ones that will contribute to their proper development. The role of the school, i.e., the teacher, can be in encouraging media literacy, where the emphasis would be on the affirmation of critical thinking and the examination of values and messages sent by the media. The absence of media awareness in favoring desirable identities and the imposition of an unrealistic picture of reality leads to the formation of a superficial value system of the individual and the society as a whole. Accordingly, it is necessary to take their moral responsibility for the potential consequences and create new media systems in order to protect the interests of children and youth.

\section{References}

Anderson, C. A., \& Bushman B. J. (2001). Effects of violent video games on aggressive behaviour, aggressive behaviour, aggressive cognition, aggressive affect, psychologicalarousal, and prosocial behaviour: A meta-analytic review ofthe scientic literature. American Psychological Society, 12(5), 353-359. https://doi.org/10.1111/1467-9280.00366

Anderson, C. A., \& Bushman B. J. (2001). Effects of violent video games on aggressive behaviour, aggressive behaviour, aggressive cognition, aggressive affect, psychologicalarousal, and prosocial behaviour: A meta-analytic review ofthe scientic literature. American Psychological Society, 12(5), 353-359. https://doi.org/10.1111/1467-9280.00366

Bowker, J. C., Thomas, K. K., Spencer, S. V., \& Park, L. E. (2013). Examining appearance-based rejection sensitivity during early adolescence. Journal of Research on Adolescence, 23(2), 375388. https://doi.org/10.1111/jora.12003

Bulu, S., Numanoglu, M., \& Keser, H. (2016). Examination of the attitudes of middle school students toward social media. Cypriot Journal of Educational Sciences, 11, 43-48. https://doi.org/10.18844/cjes.v11i1.432

Coyne, S. M. (2016). Effects of viewing relational aggression on television on aggressive behavior in adolescents: A three-year longitudinal study. Developmental Psychology, 52(2), 284-295. https://psycnet.apa.org/doi/10.1037/dev0000068

Dhawale, M. K. R. (2017). Student's involvement in different social activities through social media. International Journal of Advances in Computing and Management, 6(1), 19-20. http:// www.dypimca.ac.in/images/ResearchCentre/July-Dec2017\%20\%281\%29.pdf\#page=22

Eisen, S., \& Lillard, A. S. (2017). Young children's thinking about touchscreens versus other media in the US. Journal of Children and Media, 11(2), 167-179. http://dx.doi.org/10.1080/17482798.20 16.1254095

Gajić O., \& Lungulov, B. (2012). Uticaj masovnih medija na moralne vrednosti darovitih [The influence of mass media on moral values of the gifted]. In G. Gojkov, \& A. Stojanović (Eds.), Darovitost $i$ moralnost [Giftedness and Morality] (pp. 335-347). College of Vocational Studies for Educators. https://bit.ly/31RxXkE

Gentile, D. A., Saleem, M., \& Anderson, C. A. (2007). Public policy and the effects of media violence on children. Sociallssues and Policy Review, 1(1), 15-61. https://doi.org/10.1111/j.17512409.2007.00003.x 
Bisera JEVTIĆ, Danijela MILOŠEVIĆ. Adolescents' preferences for media content and their perceptions of dominant value orientations in the media

Hamer, A. H., \& Konijn, E. A. (2015). Adolescents' media exposure may increase their cyberbullying behavior: A longitudinal study. Journal of Adolescent Health, 56(2), 203208. https://doi.org/10.1016/j.jadohealth.2014.09.016

Hughes, C., Spicer, B., Lancaster, K., Matthew-Simmons, F., \& Dillon, P. (2010). Monograph No. 19: Media reporting on illicit drugs in Australia: Trends and impacts on youth attitudes to illicit drug use. DPMP Monograph Series. National Drug and Alcohol Research Centre. https://bit. $1 \mathrm{y} / 3 \mathrm{k} 9 \mathrm{VpcC}$

Ilišin, V. (2006). Mladi između želja i mogućnosti: položaj, problemi i potrebe mladih Zagrebačke županije [The young between their wishes and possibilities]. Institute for Social Research.

Ilišin, V., Marinović, B. A., \& Radin, F. (2001). Korišćenje masovnih medija [Mass Media Use]. In V. Ilišin (Ed.), Djeca $i$ mediji [Children and the media] (pp.132-164). State Institute for Family, Maternity and Youth Protection. Institute for Social Research. https://bit.ly/33NqCvT

Jackson, S., \& Vares, T. (2015). Too many bad role models for us girls': Girls, female pop celebrities and 'sexualization. Sexualities, 18(4), 480-498. https://doi.org/10.1177\%2F1363460714550905

Jevtić, B. (2012). Jačanje socijalnih kompetencija unutar interkulturalnih vršnjačkih grupa [The growth of social competence within multicultural peer groups]. Pedagogijska istraživanja, 9(1-2), 103115. https://hrcak.srce.hr/file/167680

Jevtić, B. (2012). Pedagogija moralnosti [Pedagogy of morality]. Faculty of Philosophy.

Kartal, O. Y. (2018). Investigating the effectiveness of media research on noticing media effects: a multiple case study. World Journal of Education, 8(4), 159-169. https://doi.org/10.5430/wje.v8n4p159

Krahé, B., Möller, I., Huesmann, L. R., Kirwil, L., Felber, J., \& Berger, A. (2011). Desensitization to media violence: Links with habitual media violence exposure, aggressive cognitions, and aggressive behavior. Journal of personality and social psychology, 100(4), 630. http://dx.doi.org/10.1037/a0021711

Kuzmanović, D., Pavlović, Z., Popadić, D., i Milošević, T. (2019). Korišćenje interneta i digitalne tehnologije kod dece i mladih u Srbiji: rezultati istraživanja deca Evrope na internetu [Use of the Internet and digital technology by children and young people in Serbia: Results of the research children of Europe on the Internet.]. Faculty of Philosophy.

Labaš, D. (2018). Prikaz knjige Digitalna demencija. Kako mi i naša djeca silazimo s uma, od Manfred Spitzer [Book Review Digital Dementia. What we and our children are doing to our minds, from Manfred Spitzer.]. Medijska istraživanja, 24(2), 113-116. https://hrcak.srce.hr/216918

McKenney, S. J., \& Bigler, R. S. (2016). Internalized sexualization and its relation to sexualized appearance, body surveillance, and body shame among early adolescent girls. The Journal of Early Adolescence, 36(2), 171-197.https://doi.org/10.1177\%2F0272431614556889

Oliver, M. B., \& Raney, A. A. (2014). Media and social life. Routledge.

Plaisier, X. S., \& Konijn, E. A. (2013). Rejected by peers- attracted to antisocial media content: Rejectionbased anger impairs moral judgment among adolescents. Developmental Psychology, 49(6), 11651173. https://psycnet.apa.org/doi/10.1037/a0029399

Popadić, D., \& Kuzmanović, D. (2016). Mladi u svetu interneta: Korišćenje digitalne tehnologije, rizici $i$ zastupljenost dititalnog nasilja među učenicima $u$ Srbiji [Youth in the world of the Internet: The use of digital technology, risks and the prevalence of digital violence among students in Serbia]. Ministry of Education, Science and Technological Development. http://www.mpn.gov.rs/ wp-content/uploads/2015/08/Mladi_u_svetu_interneta_web.pdf

Richardson, A. J., \& Ampt, E. S. (1995). Survey methods for transport planning. http://www.no2hcf. co.uk/docs/Traffic_survey_form.pdf

Rousseau, A., Trekels, J., \& Eggermont, S. (2018). Preadolescents' reliance on and internalization of media appearance ideals: Triggers and consequences. The Journal of Early Adolescence, 38(8), 1074-1099. https://bit.ly/2Hy5r9f

Shah, T. (2017). Societal Curriculum: Effects of television on social values system in Pakistani society. Bulletin of Education and Research, 39(1), 75-89. https://eric.ed.gov/?id=EJ1210114

Siddiqui, S., \& Singh, T. (2016). Social media its impact with positive and negative aspects. International Journal of Computer Applications Technology and Research, 5(2), 71-75. https://bit.ly/37ermgf

Slater, M. D., Henry, K. L., Swaim, R. C., \& Anderson, L. L. (2003). Violent media content and aggressiveness in adolescents: A downward spiral model. Communication Research, 30(6), 713736. http://dx.doi.org/10.1177/0093650203258281 
Bisera JEVTIĆ, Danijela MILOŠEVIĆ. Adolescents' preferences for media content and their perceptions of dominant value orientations in the media

PROBLEMS

OF EDUCATION

IN THE $21^{\text {st }}$ CENTURY Vol. 79 , No. 1,2021

Tatangelo, G. L., \& Ricciardelli, L. A. (2017). Children's body image and social comparisons with peers and the media. Journal of Health Psychology, 22(6), 776787.https://doi.org/10.1177\%2F1359105315615409

Tompson, K. (2003). Moralna panika [Moral panic]. Clio.

Vuksanović, D. (2018). Filozofija medija: je li nasilje zabavno? [Philosophy of media: Is violence funny?]. Ćasopis filozofije medija, 7(12), 1821-1832. https://hrcak.srce.hr/200697

Zilka, G. C., \& Romi, S. (2018). Viewing habits and identification with television characters among atrisk and normative children and adolescents. International Journal of Child, Youth and Family Studies, 9(3), 47-67. https://doi.org/10.18357/ijcyfs93201818276

Received: June 16, 2020

Accepted: January 10, 2021

Cite as: Jevtič, B. S., \& Miloševič, D. R. (2021 ). Adolescents' preferences for media content and their perceptions of dominant value orientations in the media. Problems of Education in the $21^{\text {st }}$ Century, 79(1), 34-46. https://doi.org/10.33225/pec/21.79.34

Bisera S. Jevtić

(Corresponding author)
PhD, Full Professor, University of Niš, Department of Pedagogy, Ćirila i Metodija 2, 18000 Niš, Serbia.

E-mail: bisera.jevtic@filfak.ni.ac.rs

Website: https://www.filfak.ni.ac.rs/nastavno-osoblje/pedagogija/item/136bisera-jevtic

ORCID: https://orcid.org/0000-0003-4894-7175

Danijela R. Milošević
PhD Student, University of Niš, Department of Pedagogy, Ćirila i Metodija 2, 18000 Niš, Serbia.

E-mail: danijelamilosevic1993@gmail.com

ORCID: https://orcid.org/0000-0001-9612-8807 